\title{
Pengaruh Model Pembelajaran Discovery Learning Tipe POE dan Aktivitas Belajar terhadap Kemampuan Metakognitif
}

\author{
Dwi Susanti ${ }^{1}$, Chairul Anwar ${ }^{2}$, Fredi Ganda Putra ${ }^{3}$, Netriwati ${ }^{4}$, Kiki Afandi ${ }^{5}$, \\ Santi Widyawati ${ }^{6}$ \\ 1,2,3,4,5 Pendidikan Matematika, Universitas Islam Negeri Raden Intan, Bandar Lampung \\ ${ }^{6}$ Pendidikan Matematika, Universitas Nahdlatul Ulama, Lampung \\ *fredigpsw@radenintan.ac.id
}

\begin{abstract}
Abstrak
Menghafal rumus-rumus tanpa memahami konsepnya merupakan suatu kendala dalam aktivitas belajar peserta didik saat ini. Oleh sebab itu, perlu diterapkannya pembelajaran yang bisa membuat peserta didik untuk aktif dalam memahami konsep materi yang pendidik berikan di kelas. Tujuan penelitian ini untuk mengetahui: (1) pengaruh model pembelajaran Discovery Learning tipe POE ( Preiction, observation, and Explanation) terhadap kemampuan metakognitif; (2) pengaruh aktivitas belajar terhadap kemampuan metakognitif; (3) interaksi antara model pembelajaran Discovery Learning tipe POE dan aktivitas belajar terhadap kemampuan metakognitif. Penelitian ini menerapkan penelitian eksperimen, yaitu dilaksanakan melalui eksperimentasi atau percobaan. Jenis eksperimen yang digunakan yaitu Quasy Experiment, yaitu desain yang mempunyai kelompok kontrol, tetapi tidak sepenuhnya berfungsi untuk mengontrol variabel-variabel luar yang mempengaruhi pelaksanaan eksperimen. Hasil dari penelitian menunjukkan bahwa: (1) terdapat pengaruh model pembelajaran Discovery Learning tipe POE terhadap kemampuan metakognitif; (2) terdapat pengaruh aktivitas belajar terhadap kemampuan metakognitif peserta didik; (3) tidak ada interaksi antara model pembelajaran Discovery Learning tipe POE dan aktivitas belajar terhadap kemampuan metakognitif peserta didik. Kata kunci: Aktivitas Belajar; Discovery Learning; Metakognitif.
\end{abstract}

\begin{abstract}
Remembering formulas without understanding its concept is a constraint in students' learning activities. Therefore, the learning model needs to be implemented to make students active in understanding the concept of the material that teachers provide. This research intention is to reveal: (1) the effect of the discovery learning model of POE learning type towards metacognitive ability; (2) the influence of learning activity towards metacognitive ability; (3) the interaction between discovery learning model of $\mathrm{POE}$ learning type and learning activity toward metacognitive ability. This research applied experimental research; it was conducted through experiments or trials. It used a QuasyExperimental design that has control group design, but it does not fully function to control the external variables that affect the execution of the experiment. The research outcomes show: (1) there is an effect of discovery learning model of POE learning type towards metacognitive ability; (2) there is an influence of learning activity towards students' metacognitive ability; (3) there is no interaction between discovery learning model of POE learning type and learning activity toward students' metacognitive ability.

Keywords: Learning Activity; Discovery Learning; Metacognitive.
\end{abstract}




\section{PENDAHULUAN}

Pendidikan adalah proses membina, mendidik, mengawasi, mengendalikan, memengaruhi, dan menstransmisikan ilmu pengetahuan yang dilaksanakan oleh pendidik dengan tujuan meningkatkan pengetahuan, membebaskan kebodohan serta membentuk kepribadian yang lebih baik dan bermanfaat dalam kehidupan (Sutrisno, 2014). Tujuan pendidikan yaitu mengembangkan kemampuan berpikir, bersikap rasional dan dinamis, berpandangan luas, serta agar peserta didik memiliki motivasi bahwa pendidikan yang diberikan berkaitan dengan peranan dan kedudukan mereka sebagai individu, anggota keluarga, anggota masyarakat, dan sebagai warga Negara Indonesia yang terdidik serta bertekad dan bersedia dalam mewujudkannya (Sani, 2014).

Salah satu faktor yang mempengaruhi berhasil tidaknya tujuan pendidikan ialah proses pembelajaran itu sendiri. Pembelajaran adalah usaha sadar dari guru untuk membuat peserta didik belajar, yaitu terjadinya perubahan tingkah laku pada diri peserta didik yang belajar, dimana perubahan itu dengan didapatkannya kemampuan baru yang berlaku dalam waktu yang relatif lama karena adanya usaha (Fathurrohman, 2017).

Livingstone menegaskan bahwa kemampuan metakognitif merupakan pengetahuan yang diperoleh peserta didik tentang proses-proses kognitif yaitu pengetahuan yang bisa digunakan untuk mengontrol proses-proses kognitif (Livingstone, 1997). Kemampuan metakognitif mengacu pada pengetahuan tentang proses pemecahan masalah, pemahaman tentang konsep dan ide yang terdapat dalam mata pelajaran matematika. Kemampuan metakognitif berhubungan dengan aktivitas peserta didik, kompleksitas tugas, serta kesadaran mental terhadap pemecahan masalah (Hastuti \& Sutarto, 2017). Peserta didik yang memiliki kemampuan metakognitif yang baik cenderung akan dapat menyelesaikan masalah dengan baik melalui kesadaran dan pengaturan berpikirnya (Rahayu, Widiyatmoko, \& Hartono, 2015). Minimnya partisipasi peserta didik dalam proses pembelajaran matematika seperti peserta didik hanya menghafal rumus-rumus tanpa memahami konsepnya namun peserta didik cenderung pasif dan tidak berperan aktif dalam proses pembelajaran.

Salah satu model pembelajaran yang dapat menjawab kebutuhan pendidikan dan permasalahan pendidikan yang sesuai dengan Kurikulum 2013 adalah model pembelajaran Discovery Learning Tipe POE (Prediction, Observation, and Explanation). Discovery Learning adalah model pembelajaran untuk mengembangkan peserta didik aktif dengan cara mencari tahu sendiri, menyelidiki sendiri, sehingga hasil yang diperoleh akan bertahan lama di memori, dan tidak mudah dilupakan oleh peserta didik. Discovery Learning membuat 
peserta didik belajar untuk berpikir analisis dan mencoba untuk memecahkan masalah mereka sendiri.

Model pembelajaran Discovery Learning Tipe POE (Prediction, Observation, and Explanation) merupakan suatau pembelajaran yang melibatkan peserta didik aktif dalam proses pembelajaran, khususnya dalam mata pelajaran matematika. Kegiatan dalam tipe POE yang meliputi memprediksi (prediction) mengamati (observation), dan menjelaskan (explanation) akan dapat membentuk struktur kognitif peserta didik menjadi lebih baik, karena kegiatan tersebut memberikan kesempatan kepada peserta didik untuk belajar secara konkret. POE (Prediction, Observation, and Exlanation) merupakan salah satu tipe pembelajaran yang dapat mengembangkan kemampuan metakognitif peserta didik, dengan melatih peserta didik untuk aktif terlebih dahulu mencari pengetahuan sesuai dengan cara berpikirnya (Yanuarti, 2018). Model Discovery learning telah digunakan peneliti terdahulu untuk meningkatkan suatu kemampuan seperti guna meningkatkan hasil belajar yang dimana hasilnya menunjukan bahwa model Discovery learning mampu meningkatkan hasil belajar siswa SD (Kristin, 2016), penelitian lain mengungkapkan discovery learning mampu meningkatkan motivasi dan hasil belajar pada pendidikan kewarganegaraan, prestasi belajar (Bagja \& Yuliana, 2019; Catur, Istiana, \& Sukardjo, 2015).

Menurut hasil penelitian beberapa ahli menunjukkan bahwa pengaruh penggunaan POE (Prediction, Observation, and Explanation) membuat prestasi belajar, proses pengetahuan dan keterampilan, serta kemampuan metakognitif peserta didik lebih baik dibandingkan dengan pembelajaran menggunakan metode konvensional (Rahayu, Widiyatmoko, \& Hartono, 2015).

Pengaruh penggunaan POE pada peningkatan kemampuan metakognitif telah dilakukan. Pada dasarnya kemampuan metakognitif mengharuskan siswa mampu dan sadar untuk pemecahan masalah. Pemecahan masalah siswa akan sangat berpengaruh pada aktivitas belajar siswa. Aktivitas belajar merupakan suatu kegiatan yang dilakukan untuk menghasilkan perubahan pengetahuan, nilai sikap, dan keterampilan peserta didik sebagai latihan yang dilaksanakan secara sengaja (Hasmiati, Jamilah, \& Mustami, 2017). Belajar membutuhkan adanya aktivitas, karena tanpa adanya aktivitas proses belajar tidak mungkin berjalan dengan baik. Aktivitas belajar merupakan aktivitas yang bersifat fisik maupun mental (Aliwanto, 2017). Suatu pembelajaran harus dapat mendukung peserta didik untuk melakukan aktivitas, karena aktivitas sangat berpengaruh pada hasil belajar dan prestasi peserta didik ( Ayuwanti, 2017). 
Para peneliti terdahulu telah melakukan penelitian yang ditinjau pada aktivitas dan hasil atau prestasi, terutama pada aktivitas belajar. Penelitian pada pengujian efektivitas model pembelajaran TPS yang ditinjau dari aktivitas belajar dan memiliki hasil bahwa model TPS ini efektif (Suriati, 2019). Penelitian lain pun aktivitas belajar ditingkatkan dengan penerapan pendekatan SAVI dan disimpulkan bahwa memiliki peningkatan hasil belajar setelah menerapkan pendekatan SAVI ( Sarnoko, Ruminiati, \& Setyosari, 2016). Pada penelitian lain pun telah melakukan pengujian guna meningkatkan aktivitas dan prestasi belajar dengan menerapkan Discovery learning dan mendapatkan hasil bahwa model pembelajaran ini dapat meningkatkan aktivitas dan prestasi belajar (Catur, Istiana, \& Sukardjo, 2015).

Dari beberapa pemaparan yang telah ada, makan interaksi antara model pembelajaran POE dan aktivitas belajar merupakan kebaharuan dalam penelitian ini. Berdasarkan pokokpokok bahasan diatas telah banyak pengujian tentang model yang kami ambil maka peneliti akan melakukan penelitian dengan judul "Pengaruh Model Pembelajaran Discovery Learning Tipe POE (Prediction, Observatio, and Explanation) Terhadap Kemampuan Metakognitif ditinjau dari Aktivitas Belajar Peserta Didik.

\section{METODE}

Penelitian ini menggunakan pendekatan kuantitatif, yaitu dengan instrumen yang valid dan realibel serta analisis statistik yang sesuai agar hasil penelitian yang dicapai tidak menyimpang dari kondisi sesungguhnya (Yusuf, 2016). Pemilihan metode ini dikarenakan peneliti akan mengitung data-data tentang kemampuan metakognitif peserta didik. Penelitian ini menerapkan penelitian eksperimen, yaitu dilaksanakan melalui eksperimentasi atau percobaan. Jenis eksperimen yang digunakan yaitu Quasy Experiment, yaitu desain yang mempunyai kelompok kontrol, tetapi tidak sepenuhnya berfungsi untuk mengontrol variabelvariabel luar yang mempengaruhi pelaksanaan eksperimen (Sugiyono, 2017). Penelitian ini akan dilakukan pada dua kelas, yaitu kelas eksperimen dan kelas kontrol. Kelas eksperimen akan diberikan perlakukan pembelajaran dengan menggunakan model pembelajaran Discovery Learning Tipe POE (Prediction, Observation, and Explanation) ditinjau dari aktivitas belajar peserta didik, sedangkan kelas kontrol akan diberikan perlakukan pembelajaran dengan menggunakan model pembelajaran konvensional ditinjau dari aktivitas belajar peserta didik.

Populasi pada penelitian ini adalah semua peserta didik kelas VII SMP Negeri 36 Bandar Lampung yang terdiri dari 4 kelas yaitu, A, B, C, D. Sampel adalah sebagian kecil dari populasi yang dipilih untuk observasi dan analisis. Sampel pada penelitian ini diambil 
dari kelas VII SMP Negeri 36 Bandar Lampung. Dua kelas akan dipilih menjadi sampel penelitian. Satu kelas sebagai kelas eksperimen, dan satu kelas lainnya sebagai kelas kontrol. (Aliwanto, 2017). Metode pengambilan sampel menggunakan pengambilan sampel secara acak di mana peneliti membuat kerangka pengambilan sampel dengan menggunakan proses acak murni untuk memilih kasus sehingga setiap elemen sampel dalam populasi akan memiliki probabilitas yang sama untuk dipilih. Penelitian ini menggunakan metode pengambilan dengan cara undian.

Hipotesis dalam penelitian ini adalah: (1) terdapat pengaruh model pembelajaran Discovery Learning tipe POE terhadap kemampuan metakognitif; (2) terdapat pengaruh aktivitas belajar terhadap kemampuan metakognitif; (3) ada interaksi antara model pembelajaran Discovery Learning tipe POE dan aktivitas belajar terhadap kemampuan metakognitif. Uji anova dua jalan digunakan untuk menguji hipotesis dalam penelitian ini.

\section{HASIL PENELITIAN}

Data pengambilan tes dilakukan setelah proses pembelajaran selesai guna untuk mengetahui kemampuan metakognitif peserta didik. Berikut ini adalah data hasil tes peserta didik.

Tabel 1. Deskripsi Data Amatan Tes Kemampuan Metakognitif

\begin{tabular}{cccccccc}
\hline Kelas & $\boldsymbol{X}_{\text {maks }}$ & $\boldsymbol{X}_{\min }$ & \multicolumn{2}{c}{ Ukuran Tendensi Sentral } & \multicolumn{2}{c}{$\begin{array}{c}\text { Ukuran Variansi } \\
\text { Kelompok }\end{array}$} \\
\hline & & & $\overline{\boldsymbol{X}}$ & Me & Mo & $\mathbf{R}$ & $\mathbf{S}$ \\
\hline Eksperimen & 97,83 & 58,7 & 75,436 & 75 & 69,57 & 39,13 & 10,341 \\
\hline Kontrol & 93,48 & 39,13 & 66,303 & 67,39 & 63,04 & 54,35 & 13,153
\end{tabular}

Sumber: Perhitungan ( Pengolahan Data)

Berdasarkan tabel 1, bahwa pada data amatan tes menunjukkan kemampuan metakognitif pada kelas eksperimen dan kelas kontrol menunjukan bahwa model pembelajaran ini lebih berpengaruh terhadap kemampuan metakognitif siswa dibandingkan model konvensional. Dilihat dari nilai rata rata yang dimana pada kelas eksperimen 97,83 dan pada kelas kontrol 93,48.

Angket yang telah dibagikan pada peserta didik selanjutnya dikumpulkan untuk kemudian dianalisis. Data angket yang telah dianalisis tersebut dikategorikan dalam 3 kriteria yang dapat dilihat dalam tabel 2 berikut. 
Tabel 2. Deskripsi Data Amatan Angket Aktivitas Belajar

\begin{tabular}{cccccc}
\hline \multirow{2}{*}{ Kelas } & \multirow{\boldsymbol{X}}{*}{$\mathbf{S}$} & & \multicolumn{3}{c}{ Kriteria Aktivitas Belajar } \\
\cline { 4 - 6 } & & & Tinggi & Sedang & Rendah \\
\hline Eksperimen & 86,567 & 11,805 & 6 & 20 & 4 \\
Kontrol & 84,333 & 11,586 & 4 & 20 & 6 \\
\hline
\end{tabular}

Sumber: Perhitungan( Pengolahan Data)

Data hasil tes tersebut, kemudian data dinalisis guna untuk menjawab hipotesis dari penelitian. uji hipotesis yang dipakai adalah uji hipotesis anava dua jalan sel tak sama. Sebelum dilaksanakan uji hipotesis, maka terlebih dahulu dilakukan uji prasyarat yakni uji normalitas dan homogenitas yang dijelaskan berikut ini. Hasil dari pengujian itu diperoleh bahwa semua kelompok terdistribusi normal dan homogen.

Uji anava dua jalan dilakukan guna mengetahui tingkat signifikan antara efek serta interaksi dua variabel bebas dan satu variabel terikat yang berlandaskan pada kategori kemampuan metakogntif dan aktivitas belajar tinggi, sedang, dan rendah. Data hasil perhitungan dapat dilihat berikut ini:

Tabel 3. Rangkuman Analisis Variansi Dua Jalan

\begin{tabular}{lccccc}
\multicolumn{1}{c}{ Sumber } & JK & dK & RK & F $_{\text {hitung }}$ & F tabel \\
\hline Pemberlajaran (A) & 370,671 & 1 & 370,671 & 7,153 & 4,020 \\
\hline Aktivitas (B) & 274 & 2 & 1372,5 & 26,485 & 3,168 \\
\hline Interaksi (AB) & 88,2 & 2 & 44,100 & 0,851 & 3,168 \\
\hline Galat & 2798,4 & 54 & 51,822 & - & - \\
\hline Total & $6002 ., 271$ & 59 & - & - & - \\
\hline
\end{tabular}

Berdasarkan hasil perhitungan analisis pada Tabel 3 dapat disimpulkan:

a. $\quad F_{a}=7,153$ dengan taraf signifikansi 0.05 diperoleh $F_{(0,05 ; 1 ; 54)}=4,020$ sehingga $F_{a}>F_{(0,05 ; 1 ; 54)}$ menunjukkan bahwa $H_{0 A}$ ditolak yang berarti terdapat pengaruh model pembelajaran Discovery Learning Tipe POE terhadap kemampuan metakognitif.

b. $\quad F_{b}=26,485$ dengan taraf signifikansi 0,05 diperoleh $F_{(0,05 ; 2 ; 54)}=3,168$ sehingga $F_{b}>F_{(0,05 ; 2 ; 54)}$ menunjukkan bahwa $H_{0 B}$ ditolak yang berarti terdapat pengaruh aktivitas belajar tinggi, sedang, dan rendah terhadap kemampuan metakognitif.

c. $\quad F_{a b}=0,851$ dengan taraf signifikansi 0,05 diperoleh $F_{(0,05 ; 2 ; 54)}=3,168$ sehingga $F_{b}<F_{(0,05 ; 2 ; 54)}$ menunjukkan bahwa $H_{0 A B}$ diterima.

\section{Uji Lanjut Pasca Anava}

Metode yang digunakan untuk uji lanjut pasca anava adalah metode Scheffe. Uji ini dipakai pada hipotesis penelitian yang ditolak yakni $\mathrm{H}_{0 \mathrm{~A}}$ dan $\mathrm{H}_{0 \mathrm{~B}}$. Rekapitulasi rerataan marginal bisa diantaranya: 
1. Komperasi Ganda Antar Baris

Berdasarkan tabel sebelumnya didapat $F_{a}=7,153$ dan $F_{\text {tabel }}=4,020$ yang berarti $H_{O A}$ ditolak, artinya terdapat pengaruh antara peserta didik yang mendapatkan perlakuan model pembelajaran Discovery Learning tipe POE serta peserta didik dengan perlakuan model pembelajaran konvensional. Penelitian ini hanya menggunakan dua model pembelajaran, maka untuk antar baris tidak perlu dilakukan komperasi pasca anava. Untuk mengetahui perlakuan manakah yang lebih baik dari dua perlakuan tersebut uji komperasi ganda antar baris tidak diperlukan, cukup dengan melihat perbandingan dari rataan marginal antar barias dari dua perlakuan model tersebut. Berdasarkan tabel 3 terlihat bahwa rataan marginal untuk perlakuan dengan menggunakan model pembelajaran Discovery Learning tipe POE adalah 77,6 sedangkan rataan marginal perlakuan dengan menggunakan model pembelajaran konvensional adalah 71,4, yang artinya bahwa 77,6 > 71,4. Sehingga, dapat disimpulkan bahwa model pembelajaran Discovery Learning tipe POE dapat berpengaruh.

\section{Komparasi Ganda Antar Kolom}

Berdasarkan perhitungan rataan marginal pada tabel 3 yang menunjukkan bahwa rataan marginal antar kolom kategori aktivitasi belajar berbeda-beda, tidak semua aktivitas belajar yang dimiliki peserta didik bisa memberikan dampak yang sama terhadap kemampuan metakognitif peserta didik. Selanjutnya, membandingkan manakah yang memiliki rataan berbeda perlu dilaksanakan uji komperasi ganda antar kolom. Rekapitulasi dari komperasi tersebut adalah sebagai berikut:

Tabel 4. Perhitungan Uji Komparasi Ganda Antar Kolom

\begin{tabular}{ccccc}
\hline No & $\mathbf{H}_{\mathbf{0}}$ & $\mathbf{F}_{\text {hitung }}$ & $\mathbf{F}_{\text {tabel }}$ & Keputusan Uji \\
\hline 1 & $\mu_{1} v s \mu_{2}$ & 32,457 & 6,336 & $\mathrm{H}_{0}$ ditolak \\
\hline 2 & $\mu_{1} v s \mu_{3}$ & 38,593 & 6,336 & $\mathrm{H}_{0}$ ditolak \\
\hline 3 & $\mu_{2} v s \mu_{3}$ & 4,670 & 6,336 & $\mathrm{H}_{0}$ diterima \\
\hline
\end{tabular}

Sumber: Perhitungan (Pengolahan Data)

Berdasarkan Tabel 4, dapat disimpulkan beberapa hal sebagai berikut:

a. Hasil perhitungan antara $\mu_{1} v s \mu_{2}$ didapat $F_{\text {hitung }}>F_{\text {tabel }}$ yang berarti $\mathrm{H}_{0}$ ditolak. Sehingga terdapat pengaruh yang signifikan antara aktivitas belajar tinggi serta aktivitas belajar sedang terhadap kemampuan metakognitif. Berdasarkan tabel 4 terlihat bahwa rerata marginal aktivitas tinggi, yaitu 86 lebih besar dari pada rerata marginal aktivitas sedang, yaitu 71,5. Maka dapat dapat disimpulkan bahwa peserta didik yang termasuk dalam kategori aktivitas belajar tinggi lebih baik dari pada 
peserta didik yang termasuk kategori aktivitas belajar sedang terhadap kemampuan metakognitif.

b. Hasil perhitungan antara $\mu_{1} v s \mu_{3}$ diperoleh $F_{\text {hitung }}>F_{\text {tabel }}$ yang berarti $\mathrm{H}_{0}$ ditolak. Sehingga terdapat pengaruh yang signifikan antara aktivitas belajar tinggi serta aktivitas belajar rendah terhadap kemampuan metakognitif. Berdasarkan tabel 4 terlihat bahwa rerata marginal aktivitas tinggi, yaitu 86 lebih besar dari pada rerata marginal aktivitas rendah, yaitu 66. Maka dapat disimpulkan bahwa peserta didik yang termasuk dalam kategori aktivitas belajar tinggi lebih baik dari pada peserta didik yang termasuk kategori aktivitas belajar rendah terhadap kemampuan metakognitif.

c. Hasil perhitungan antara $\mu_{2} v s \mu_{3}$ didapatkan $F_{\text {hitung }}<F_{\text {tabel }}$ yang berarti $\mathrm{H}_{0}$ diterima. Sehingga tidak terdapat pengaruh yang signifikan antara aktivitas belajar yang sedang dan aktivitas belajar yang rendah terhadap kemampuan metakognitif.

Penelitian ini mempunyai dua variabel yang dijadikan objek dalam penelitian, yang pertama variabel bebas yakni model pembelajaran Discovery Learning tipe POE dan aktivitas belajar, serta variabel terikat yakni kemampuan metakognitif.

\section{PEMBAHASAN}

Berdasarkan data hasil analisis serta pengujian hipotesis, maka berikut ini adalah pembahasan dari hasil penelitian yang antara lain:

\section{Hipotesis Pertama}

Berdasarkan hasil perhitungan dengan menggunakan analisis variansi dua jalan sel tak sama diperoleh hipotesis yang pertama, yaitu terdapat perbedaan pengaruh antara model pembelajaran dengan kemampuan metakognitif. Disimpulkan bahwa terdapat pengaruh yang signifikan antara model pembelajaran Discovery Learning tipe POE dan model pembelajaran konvensional terhadap kemampuan metakognitif peserta didik, hal tersebut dilihat bahwa $F_{\text {hitung }}>F_{\text {tabel }}$ yang artinya $\mathrm{H}_{0 \mathrm{~A}}$ ditolak. Selain uji anava, dilakukan juga uji komparasi ganda yang diperoleh bahwa rerata dari perlakukan dengan model pembelajaran Discovery Learning tipe POE lebih baik dari perlakukan model pembelajaran konvensional. Jadi, dapat disimpulkan bahwa kemampuan metakognitif yang diajarkan dengan menggunakan model pembelajaran Discovery Learning tipe POE lebih baik dari pada menggunakan model pembelajaran konvensional. 
Proses pembelajaran di SMP 36 Negeri Bandar Lampung dengan menggunakan model pembelajaran Discovery Learning tipe POE, menjadikan peserta didik lebih antusias dalam mengikuti kegiatan pembelajaran di kelas. Sebelum guru memasuki ruang kelas peserta didik sudah menduduki tempat duduk dengan rapi serta telah menyiapkan perlengkapan alat tulis dan buku. Saat proses pembelajaran peserta didik terlihat semangat serta aktif dalam pembelajaran, peserta didik mampu berdiskusi serta dapat saling bertukar pendapat bersama kelompoknya untuk mendapatkan jawaban serta kesimpulan dari materi yang diajarkan serta mampu mempersentasikannya dihadapan teman-temannya yakni materi aritmatika sosial. Guru hanya memberikan pengawasan pada peserta didik. Saat proses pembelajaran, jika ada peserta didik yang bertanya tentang hal yang kurang dipahami, maka disini yang akan memjawab pertanyaan adalah peserta didik lainnya. Kegiata ini peserta didik bisa saling berinteraksi antar peserta didik lainnya guna menjelaskan kembali konsep yang disampaikan guru serta mampu menyelesaikan soal yang diberikan guru dengan langkah-langkah yang tepat dan benar, hal ini dikarenakan pada dasarnya kemampuan metakognitif dalam proses pembelajaran dapat membantu peserta didk untuk merencanakan, memonitor pelaksanaan, mengevaluasi / refleksi serta dapat meyelesaikan masalah-masalah yang ada dalam matematika.

Pembelajaran konvensional adalah pembelajaran tradisional yang identik dengan metode ceramah, karena metode ini masih digunakan dalam proses pembelajaran di SMP 36 Bandar Lampung. Kegiatan diskusi serta pemberian tugas hanya diberikan pada materi-materi tertentu. Peserta didik pada kelas kontrol yang diajarkan dengan model pembelajaran konvensional terlihat kurang bersemangat dalam mengikuti proses pembelajaran. Hal tersebut terlihat saat pembelajaran akan dimulai peserta didik masih ada yang terlambat masuk kelas dan belum menyiapkan perlengkapan alat tulis dan buku. Saat pembelajaran berlangsung siswa terlihat kurang antusias serta lebih pasif untuk mengikuti proses pembelajaran dikarenakan hanya mendengar, menyimak dan mencatat materi yang telah disampaikan.

Berdasarkan beberapa paparan hal tersebut, peserta didik yang diajarkan dengan menggunakan model permbelajaran Discovery Learning tipe POE akan menghasilkan kemampuan metakognitif yang lebih baik dari pada peserta didik yang diajarkan menggunakan model pembelajaran konvensional. Hal tersebut sesuai dengan hasil penelitian yang menyatakan bahwa terhadap kemampuan metakognitif peserta didik yang mendapat perlakuan model pembelajaran Discovery Learning tipe POE lebih baik dari pada peserta didik yang mendapat perlakukan model pembelajaran konvensional. 
Hipotesis Kedua

Hipotesis kedua diperoleh bahwa terdapat pengaruh signifikan antara tingkat kategori aktivitas belajar terhadap kemampuan metakognitif peserta didik. Aktivitas yang dimiliki peserta didik terhadap proses pembelajaran matematika memiliki pengaruh terhadap hasil posttest. Hal ini terlihat berdasarkan hasil posttest kemampuan metakognitif yang diberikan pada akhir pembelajaran. peserta didik yang mendapatkan nilai tertinggi, memiliki aktivitas belajar yang tinggi saat proses pembelajaran matematika berlangsung.

Hasil perhitungan yang didapat pada analisis variansi dua jalan sel tak sama, memperoleh nilai $F_{\text {hitung }}>F_{\text {tabel }}$ yang menyatakan bahwa $\mathrm{H}_{0 \mathrm{~B}}$ ditolak, yang artinya terdapat pengaruh kemampuan metakognitif peserta didik yang mendapat perlakuan model pembelajaran Discovery Learning tipe POE yang mempunyai aktivitas belajar tinggi, sedang dan rendah. Hal tersebut menunjukkan bahwa ada perbedaan antara peserta didik yang mempunyai aktivitas belajar tinggi, sedang dan rendah saat proses pembelajaran yang mendapat perlakuan model pembelajaran Discovery Learning dan peserta didik yang belajar dengan mendapat perlakuan model pembelajaran konvensional.

Berdasarkan hasil uji pasca anava dengan melihat rataan marginalnya pada tabel 4 terlihat bahwa terdapat perbedaan signifikan antara peserta didik yang mempunyai aktivitas belajar tinggi serta aktivitas belajar sedang, terdapat perbedaan yang signifikan antara peserta didik yang memiliki aktivitas belajar tinggi dan peserta didik yang mempunyai aktivitas rendah, dan tidak terdapat perbedaan yang signifikan antara peserta didik yang mempunyai aktivitas belajar sedang dan peserta didik yang mempunyai aktivitas belajar rendah terhadap kemampuan metakognitif.

Berdasarkan hasil penelitian, bisa disimpulkan bahwa peserta didik dengan aktivitas belajar tinggi mempunyai kemampuan metakognitif yang lebih baik daripada peserta didik yang mempunyai kemampuan metakognitif dengan aktivitas belajar sedang maupun aktivitas belajar rendah.

\section{Hipotesis Ketiga}

Berdasarkan perhitungan dapat disimpulkan bahwa tidak terdapat interaksi antara perlakuan pembelajaran dengan kategori aktivitas belajar terhadap kemampuan kemampuan metakognitif peserta didik dikarenakan $F_{\text {hitung }}<F_{\text {tabel }}$ yang menerangkan bahwa $\mathrm{H}_{0 \mathrm{AB}}$ diterima, yang berarti tidak terdapat perbedaan pengaruh antara perlakuan pembelajaran dan aktivitas belajar terhadap kemampuan metakognitif peserta didik. Ketidaksesuaian hasil penelitian ini dengan teori yang ada, dikarenakan kemungkinan dalam pengisian angket yang tidak jujur. Hal tersebut dapat berpengaruh terhadap hasil data angket yang tidak sesuai 
dengan teori, yang seharusnya terdapat interaksi antara model pembelajaran dan aktivitas belajar terhadap kemampuan metakognitif peserta didik.

\section{Hipotesis ke empat}

Berdasarkan penelitian terdahulu bahwa metode Discovery learning banyak digunakan untuk pengujian kemampuan lainnya, seperti peningkatan hasil belajar , prestasi belajar, motivasi belajar (Bagja \& Yuliana, 2019; Catur, Istiana, \& Sukardjo, 2015; Kristin, 2016). Semuanya berpengaruh pada kemampuan metakognitif (Panggayuh, 2017). Jadi model pembelajaran Discovery learning efektif guna meningkatkan kemampuan metakognitif.

\section{SIMPULAN}

Berdasarkan hasil penelitian yang diperoleh mengenai model pembelajaran Discovery Learning tipe POE terhadap kemampuan metakognitif peserta didik, dapat disimpulkan bahwa terdapat pengaruh model pembelajaran Discovery Learning tipe POE terhadap kemampuan metakognitif peserta didik. Peserta didik yang diberikan perlakuan menggunakan model pembelajaran Discovery Learning tipe POE memiliki kemampuan metakognitif yang lebih baik dibandingkan dengan peserta didik yang diberikan perlakukan menggunakan model pembelajaran konvensional. Selain itu hasil menunjukkan bahwa terdapat pengaruh aktivitas belajar terhadap kemampuan metakognitif peserta didik. Kemampuan metakognitif peserta didik yang memiliki aktivitas belajar tinggi lebih baik daripada peserta didik yang memiliki aktivitas belajar sedang maupun aktivitas belajar rendah. Peserta didik yang memiliki aktivitas belajar sedang mendapatkan kemampuan metakognitif yang sama baik dengan peserta didik yang memiliki aktivitas belajar rendah, serta tidak terdapat interaksi antara perlakuan model pembelajaran serta kategori aktivitas belajar peserta didik terhadap kemampuan metakognitif peserta didik.

Berdasarkan kesimpulan dari penelitian, penulis menyarankan supaya guru disarankan bisa mengaplikasikan model pembelajaran Discovery Learning pada saat proses pembelajaran seperti matematika guna untuk meningkatkan kemampuan metakognitif peserta didik, guru harus mampu mengetahui betapa pentingnya mengembangkan kemampuan matematika peserta didik, seperti kemampuan metakognitif peserta didik, guru disarankan bisa memperhatikan aktivitas belajar yang dimiliki oleh peserta didik, peneliti-peneliti selanjutnya diharapkan untuk dapat melihat bagaimana kemampuan matematis lainnya yang dimiliki oleh peserta didik dengan mengaplikasikan penggunaan model pembelajaran Discovery Learning Tipe POE pada pokok bahasan lainnya. 


\section{REFERENSI}

Aliwanto. (2017). mengetahui layanan informasi yang telah dilaksanakan oleh guru bimbingan dan konseling tentang komunikasi interpersonal siswa kelas X Sekolah Menengah Atas Negeri 10 Pontianak . G-COUNS Jurnal Bimbingan Dan Konseling, $1(2), 136-145$.

Ayuwanti, I. (2017). Meningkatkan Aktivitas dan Hasil Belajar Matematika Menggunakan Model Pembelajaran Kooperatif Tipe Group Investigation di SMK Tuma'ninah Yasin Metro. SAP (Susunan Artikel Pendidikan), 1(2), 105-114. Doi: https://doi.org/10.30998/sap.v1i2.1017

Bagja, S. W., \& Yuliana, D. (2019). Penerapan Model Pembelajaran Discovery Learning Meningkatkan Motivasi dan Hasil Belajar Pendidikan Kewarganegaraan 1. Jurnal Rontal Keilmuan PKn, 5(1), 17-30. Doi: http://dx.doi.org/10.29100/jr.v5i1.1021

Catur, S. A. N., Istiana, G., \& Sukardjo, J. (2015). Penerapan Model Pembelajaran Discovery Learning Untuk Meningkatkan Aktivitas Dan Prestasi Belajar Pokok Bahasan Larutan Penyangga Pada Siswa Kelas XI IPA Semester II SMA Negeri 1 Ngemplak Tahun Pelajaran 2013/2014. Jurnal Pendidikan Kimia Universitas Sebelas Maret, 4(2), 65-73.

Fathurrohman, M. (2017). Belajar dan Pembelajaran Modern: Konsep Dasar, Inovasi dan Teori Pembelajaran (pp. 1-262). Yogyakarta : Garudhawaca

Hasmiati, Jamilah, \& Mustami, M. K. (2017). Aktivitas dan Hasil Belajar Siswa pada Pembelajaran Pertumbuhan dan Perkembangan dengan Metode Praktikum. Jurnal Biotek, 5(1), 21-35. Doi: https://doi.org/10.24252/jb.v5i1.3444

Hastuti, I. D., \& Sutarto. (2017). Karakteristik Pergeseran Aktivitas Metakognitif Siswa Dalam Pemecahan Masalah Matematika. Jurnal Ilmiah Mandala Education, 3(1), 450459. Doi: http://dx.doi.org/10.36312/jime.v3i1.170

Kristin, F. (2016). Analisis model pembelajaran discovery learning dalam meningkatkan hasil belajar siswa SD. Jurnal Pendidikan Dasar PerKhasa, 2(1), 90-98. Doi: https://doi.org/10.31932/jpdp.v2i1.25

Livingstone, J. A. (1997). Metacognition: An Overview. http. www, gse. buffalo, edu/fas/shuell/CEP564/Metaeog. htm.

Panggayuh, V. (2017). Pengaruh Kemampuan Metakognitif Terhadap Prestasi Akademik Mahasiswa Pada Mata Kuliah Pemrograman Dasar. JIPI (Jurnal Ilmiah Penelitian Dan Pembelajaran Informatika), 2(1), 20-25. Doi: https://doi.org/10.29100/jipi.v2i1.228 
Rahayu, P., Widiyatmoko, A., \& Hartono, H. (2015). Penerapan Strategi Poe (PredictObserve-Explain) Dengan Metode Learning Journals Dalam Pembelajaran IPA Untuk Meningkatkan Pemahaman Konsep Dan Keterampilan Proses Sains. Unnes Science Education Journal, 4(3), 1014-1021. Doi: https://doi.org/10.15294/usej.v4i3.8853

Sani, R. A. (2014). Pembelajaran Saintifik untuk Implementasi Kurikulum 2013 (1st ed.). Jakarta : Bumi Aksara

Sarnoko, S., Ruminiati, R., \& Setyosari, P. (2016). Penerapan Pendekatan Savi Berbantuan Video Pembelajaran untuk Meningkatkan Aktivitas dan Hasil Belajar IPS Siswa Kelas IV SDN I Sanan Girimarto Wonogiri. Jurnal Pendidikan - Teori, Penelitian, Dan Pengembangan, 1(7), 1235-1241. Doi: https://doi.org/10.17977/jp.v1i7.6524

Sugiyono, P. D. (2017). Metode Penelitian Bisnis: Pendekatan Kuantitatif, Kualitatif, Kombinasi, dan R\&D. Bandung: Alfabeta

Suriati, S. (2019). Analisis Prestasi Belajar Matematika: Dampak Model Pembelajaran Kooperatif Tipe Think-Pair-Square Ditinjau dari Aktivitas Belajar. Desimal: Jurnal Matematika, 2(2), 181-188. Doi: https://doi.org/10.24042/djm.v2i2.4374

Sutrisno, A. N. (2014). Telaah Filsafat Pendidikan. Yogyakarta: Deepublish

Yanuarti, S. (2018). Penerapan Pembelajaran Berbasis Predict, Observe, Explain (Poe) Pada Pembelajaran Geometri di Kelas X SMA Negeri 13 Palembang. Jurnal Pendidikan Matematika, 12(1), 71-78

Yusuf, A. M. (2016). Metode Penelitian Kuantitatif, Kualitatif \& Penelitian Gabungan. Jakarta: Fajar Interpratama Mandiri 